\title{
Studies on Nutritional and Physiological Requirement for Growth and Biomass of Hypsizygus ulmarius
}

\author{
Dheeraj Baghel*, Veer Singh, C. S. Shukla and H. K. Singh
}

Department of Plant Pathology, College of Agriculture, I. G. K. V., Raipur (C.G.), India

*Corresponding author

\begin{tabular}{|l|}
\hline K e y w o r d s \\
$\begin{array}{l}\text { H. ulmarius, Potato } \\
\text { dextrose agar } \\
\text { medium, } \\
\text { Temperature, } \\
\text { Relative humidity }\end{array}$ \\
\hline Article Info \\
\hline $\begin{array}{l}\text { Accepted: } \\
\text { 04 November } 2019 \\
\text { Available Online: } \\
\text { 10 December } 2019\end{array}$ \\
\hline
\end{tabular}

\section{A B S T R A C T}

Mushroom is a cash crop grown worldwide on small as well as commercial scale for domestic consumption and export. It is a rich source of proteins, minerals and vitamins with low calorie value with no cholesterol. It is well known alternate source of good quality protein which has higher concentration of amino acid viz., tryptophan and lysine in comparison to vegetable protein. The present investigation was carried out to know the nutritional and physiological along with growth and biomass of $H$. ulmarius. Among the tested media potato dextrose agar medium was found most suitable medium for the growth $(89.00 \mathrm{~mm})$ and biomass (fresh mycelium weight: $13.93 \mathrm{gm}$ and dry mycelium weight $0.57 \mathrm{gm}$ ) of $H$. ulmarius. Optimum temperature required $26^{\circ} \mathrm{C}$ was most suitable. Maximum relative humidity for radial growth was observed at $75 \%$ relative humidity. Complete darkness or zero hrs light was excellent for mycelial growth and biomass of $H$. ulmarius. Maximum growth of $H$. ulmarius was obtained at $\mathrm{pH} 8.0$ on potato dextrose agar medium.

\section{Introduction}

Mushrooms are valuable health food in modern society. Human beings have constantly searched for new substances than can improve biological functions and make people fitter and healthier. Recently, human beings have increasingly turned to plants, mushrooms, herbs and foods as sources of these enhances, with increasing experimentally based confirming many empirical observations throughout history relating to the beneficial effects of mushrooms on a wide range of human ailments. Furthermore, the value of mushrooms has recently been promoted to tremendous levels with clinic trials for HIV / AIDS patients in Africa, generating encouraging results. Blue oyster mushroom is a novel species with very large fruit body, blue coloured pinheads 
becoming light white on maturity, high yielder, palatable with meaty flavor and attractive keeping quality. This new mushroom variety has attractive shape and fleshy with excellent taste. In Chhattisgarh blue oyster mushroom first time cultivated by Annon (2005) and Chandrawanshi (2006). But the data pertaining to nutritional and physiological requirements for growth and spawn development and influence of prevailing environmental conditions on growth.

\section{Materials and Methods}

Effect of different media on growth of $\boldsymbol{H}$. ulmarius

Three different media i.e. Potato dextrose agar, Malt yeast extract agar, Wheat extract agar media were studied to find out suitable medium for radial growth and biomass of $H$. ulmarius.

\section{Effect of temperature}

Different levels of temperature $\left(20^{\circ} \mathrm{C}, 22^{\circ} \mathrm{C}\right.$, $24^{\circ} \mathrm{C}, 26^{\circ} \mathrm{C}$ and $28^{\circ} \mathrm{C}$ ) were used to study their impact mycelial growth of $H$. ulmarius.

\section{Effect of relative humidity}

Four different levels of relative humidity (25, 50,75 and 100 percent) were maintained to see their effect on growth of $H$. ulmarius. The relative humidity was maintained in desiccators by mixing the different quantities of concentrated $\mathrm{H}_{2} \mathrm{SO}_{4}$ and distilled water in different proportions.

\section{Effect of duration of light}

The petriplates and flasks were exposed in light for different time intervals i.e. (i) $0 \mathrm{hrs}$ light (ii) 6 hrs light (iii) $12 \mathrm{hrs} \mathrm{light} \mathrm{(iv)} 18 \mathrm{hrs}$ light (v) 24 hrs light. Each treatment had 4 replications. The observations on redial growth, fresh and dry mycelium weight were recorded after completion of growth in any treatment.

\section{Effect of pH}

Different levels of $\mathrm{pH}(4,5,6,7,8$ and 9) were studied to find out the optimum $\mathrm{pH}$ for growth of $H$. ulmarius. The $\mathrm{pH}$ was maintained in Potato dextrose agar medium and broth with the help of $\mathrm{pH}$ meter using 0.1 $\mathrm{N}, \mathrm{HCl}$ and $0.1 \mathrm{~N}, \mathrm{NaOH}$ solution.

In all experiment the plates and flask containing $20 \mathrm{ml}$ and $75 \mathrm{ml}$ PDA liquid medium respectively were inoculated pure culture $5 \mathrm{~mm}$ disc of each strains of $H$. ulmarius. The incubated plates and flask were incubated for 15 days at $30^{\circ} \mathrm{C}$. The observation was recorded for radial growth, fresh and dry biomass when the mycelium growth in any treatment reached at the periphery of the plates.

\section{Results and Discussion}

\section{Effect of different media on growth and of Hypsizygus ulmarius}

Among the tested media, significantly higher $(89.00 \mathrm{~mm})$ radial growth of $H$. ulmarius was recorded in potato dextrose agar medium and next was wheat extract agar medium (81.50 $\mathrm{mm})$, however least $(69.75 \mathrm{~mm})$ growth was noticed in malt-yeast extract agar medium. The biomass production of $H$. ulmarius was in accordance with that of radial growth. The fresh and dry mycelial weight of $H$. ulmarius differed significantly in different liquid media studied. Significantly higher fresh and dry mycelial weight (13.93 and $0.573 \mathrm{~g}$ respectively) was obtained in potato dextrose liquid medium (Fig. 1). Whereas it was lowest fresh $(10.72 \mathrm{~g})$ and dry $(0.240 \mathrm{~g})$ mycelial weight was found in malt-yeast extract agar 
medium and wheat extract agar medium (12.80 $\mathrm{g}$ fresh and $0.510 \mathrm{~g}$ dry). The above findings are in agreement with the results of Kumar et al., (2016) who reported potato dextrose agar medium suitable for growth of H. ulmarius (Table 1).

\section{Effect of different temperature on radial growth and biomass of Hypsizygus ulmarius}

The variation in temperature significantly influenced the radial growth and biomass of H. ulmarius (Table 2). Significantly higher $(88.25 \mathrm{~mm})$ myclial growth of $H$. ulmarius was recorded at $26^{\circ} \mathrm{C}$ where as it was significantly lower $(51.00 \mathrm{~mm})$ observed at $20^{\circ} \mathrm{C}$, in other temperature the growth was decrease either increasing and decreasing of temperature and it range from $63.75 \mathrm{~mm}$ $85.25 \mathrm{~mm}$. The fresh as well as dry mycelial weight of $H$. ulmarius was significantly higher noticed at $26^{\circ} \mathrm{C}(8.92$ and $0.85 \mathrm{~g})$ and next were $24^{\circ} \mathrm{C}(8.77$ and $0.76 \mathrm{~g}), 28^{\circ} \mathrm{C}(8.74$ and 0.56 g.) or $22^{\circ} \mathrm{C}(7.07$ and 0.47 g.) while it was significantly lower (5.58 and 0.38 g.) found at $20^{\circ} \mathrm{C}$. In the present investigation more growth and biomass was recorded at $26^{\circ} \mathrm{C}$ which are agreeing with findings of Sumi and Geetha (2016) (Fig. 2).

\section{Effect of relative humidity on radial growth and biomass production of Hypsizygus ulmarius}

There was significant difference in radial growth of $\mathrm{H}$. ulmarius at different levels of relative humidity. Significantly more radial growth $(87.75 \mathrm{~mm})$ of $H$. ulmarius was noticed at 75 percent relative humidity followed by $100 \%(77.50 \mathrm{~mm})$ while it was significantly less at $(56.25 \mathrm{~mm})$ noticed at $25 \%$ and 50 percent relative humidity $(61.00$ $\mathrm{mm})$. Besides radial growth, fresh mycelial and dry mycelial weight of $H$. ulmarius was also recorded significantly higher at 100 and $75 \% \mathrm{RH}$ (9.04 $\mathrm{g}$ and $8.72 \mathrm{~g}$ respectively) and it was less $(7.57 \mathrm{~g})$ and $25 \%$ relative humidity and next was 50\% (7.84g) and both were significantly differ from each other. The dry mycelial weight of $H$. ulmarius differ significantly with each other and it was more $(0.92 \mathrm{~g})$ found at $75 \% \mathrm{RH}$ then other $\mathrm{RH}$.

However, it was least noticed at $25 \%(0.40 \mathrm{~g})$ and followed by $50 \%(0.55 \mathrm{~g})$ and $100 \%$ $(0.83 \mathrm{~g})$. The present investigation closely related with the results of Hilmar (1977) explained that $70-80 \% \mathrm{RH}$ more appropriate for growth of $P$. florida. Similar types of studies were also reported by Namdev (2000) P. flabellatus (Fig. 3 and Table 3).

\section{Effect of duration of light on radial growth and biomass of Hypsizygus ulmarius}

The growth of $H$. ulmarius significantly more (89.0) observed in plates were exposed in complete darkness followed by $12 \mathrm{hrs}$ light and $12 \mathrm{hrs}$ darkness and complete light (83.25 $\mathrm{mm}$ and $80.25 \mathrm{~mm}$ respectively). However significantly less $(69.25 \mathrm{~mm})$ radial growth was noticed in plates were exposed to $18 \mathrm{hrs}$ light+6hrs darkness and 6hrs light+18hrs darkness $(79.50 \mathrm{~mm})$. In liquid culture, biomass production of $H$. ulmarius differed significantly with respect to different period of light. The fresh mycelial weight was significantly higher $(8.62 \mathrm{~g})$ obtained in broth when exposed in complete darkness $12 \mathrm{hrs}$ $(8.13 \mathrm{~g})$ light duration and $24 \mathrm{hrs}(7.99 \mathrm{~g})$ light and at par with each other whereas, it was significantly lower $(6.65 \mathrm{~g})$ recorded in $6 \mathrm{hr}$. light and $18 \mathrm{hrs}$ darkness followed by $18 \mathrm{hrs}$ (7.54g) $24 \mathrm{hrs}(7.99 \mathrm{~g})$ light period. The dry mycelial weight of $H$. ulmarius also differed significantly with respect to different period of light. The dry mycelial weight was significantly higher $(0.69 \mathrm{~g})$ in complete darkness and $24 \mathrm{hrs}$ light $(0.56 \mathrm{~g})$ and $12 \mathrm{hrs}$ light $(0.51 \mathrm{~g})$. Significantly lower $(0.32 \mathrm{~g})$ dry mycelial weight was recorded in 6hrs light and $18 \mathrm{hrs}(0.41 \mathrm{~g})$ light period and did not differ each other (Fig. 4 and Table 4). 
Table.1 Effect of different media on growth and biomass of $H$. ulmarius

\begin{tabular}{|c|c|c|c|c|c|}
\hline S.N. & Media & $\begin{array}{l}\text { Radial } \\
\text { growth } \\
(\mathbf{m m}) *\end{array}$ & Growth characteristics & $\begin{array}{l}\text { Fresh mycelial } \\
\text { weight (g.)* }\end{array}$ & $\begin{array}{l}\text { Dry mycelial } \\
\text { weight } \\
\text { (g.)* }\end{array}$ \\
\hline 1 & PDA & 89.00 & $\begin{array}{l}\text { Absolute white mycelial } \\
\text { growth, moderately fluffy in } \\
\text { nature with prominent } \\
\text { concentric rings and regular } \\
\text { margin. }\end{array}$ & 13.93 & 0.573 \\
\hline 2 & $\begin{array}{c}\text { Malt-yeast } \\
\text { extract agar }\end{array}$ & 69.75 & $\begin{array}{l}\text { Absolute white mycelium } \\
\text { growth, abundant fluffy in } \\
\text { nature with prominent } \\
\text { concentric rings and regular } \\
\text { margin. }\end{array}$ & 10.72 & 0.240 \\
\hline 3 & $\begin{array}{c}\text { Wheat } \\
\text { extract agar }\end{array}$ & 81.50 & $\begin{array}{l}\text { White mycelium submerged } \\
\text { in nature with concentric rings } \\
\text { and regular margin. }\end{array}$ & 12.80 & 0.510 \\
\hline & SEm \pm & 0.812 & & 0.561 & 0.035 \\
\hline & CD (5\%) & 2.635 & & 1.819 & 0.114 \\
\hline
\end{tabular}

Table.2 Effect of different temperature on mycelial growth and biomass of $H$. ulmarius

\begin{tabular}{|c|c|c|c|c|c|}
\hline S.N. & Treatments & $\begin{array}{l}\text { Radial } \\
\text { growth } \\
(\mathbf{m m})^{*}\end{array}$ & Growth characteristics & $\begin{array}{c}\text { Fresh } \\
\text { mycelial } \\
\text { weight }(\mathrm{g.} .)^{*}\end{array}$ & $\begin{array}{l}\text { Dry mycelial } \\
\text { weight } \\
\text { (g.)* }\end{array}$ \\
\hline 1 & $20^{\circ} \mathrm{C}$ & 51.000 & $\begin{array}{l}\text { White mycelial growth fluffy and } \\
\text { scanty growth. }\end{array}$ & 5.588 & 0.380 \\
\hline 2 & $22^{\circ} \mathrm{C}$ & 63.750 & $\begin{array}{l}\text { White mycelial growth, fluffy } \\
\text { with concentric rings and scanty } \\
\text { growth. }\end{array}$ & 7.070 & 0.475 \\
\hline 3 & $24^{\circ} \mathrm{C}$ & 85.250 & $\begin{array}{l}\text { White mycelial growth with } \\
\text { prominent concentric rings. }\end{array}$ & 8.773 & 0.765 \\
\hline 4 & $26^{\circ} \mathrm{C}$ & 88.250 & $\begin{array}{l}\text { Absolute white mycelial growth } \\
\text { with prominent concentric rings } \\
\text { and fluffy. }\end{array}$ & 8.928 & 0.850 \\
\hline 5 & $28^{\circ} \mathrm{C}$ & 82.000 & $\begin{array}{l}\text { Absolute white mycelial growth } \\
\text { with concentric rings. }\end{array}$ & 8.740 & 0.565 \\
\hline & SEm \pm & 1.863 & & 0.233 & 0.060 \\
\hline & CD $(5 \%)$ & 5.667 & & 0.710 & 0.183 \\
\hline
\end{tabular}

$*$ Average of four replications 
Table.3 Effect of different levels of RH \% on mycelial growth and biomass of $H$. ulmarius

\begin{tabular}{|c|c|c|c|c|c|}
\hline S.N. & Treatments & $\begin{array}{l}\text { Radial growth } \\
\qquad(\mathrm{mm})^{*}\end{array}$ & Growth characteristics & $\begin{array}{l}\text { Fresh mycelial } \\
\text { weight (g.)* }\end{array}$ & $\begin{array}{c}\text { Dry mycelial } \\
\text { weight } \\
(\text { g. })^{*}\end{array}$ \\
\hline 1 & $25 \%$ & 56.25 & $\begin{array}{c}\text { Absolute white mycelial growth and } \\
\text { irregular margin. }\end{array}$ & 7.575 & 0.405 \\
\hline 2 & $\mathbf{5 0 \%}$ & 61.00 & $\begin{array}{c}\text { Absolute dense white mycelial growth, } \\
\text { regular margin. }\end{array}$ & 7.843 & 0.553 \\
\hline 3 & $75 \%$ & 87.75 & $\begin{array}{l}\text { Absolute dense white mycelial growth, } \\
\text { regular margin. }\end{array}$ & 8.720 & 0.923 \\
\hline 4 & $100 \%$ & 77.50 & $\begin{array}{c}\text { Absolute dense white mycelial growth, } \\
\text { regular margin. }\end{array}$ & 9.040 & 0.830 \\
\hline & SEm \pm & 1.598 & & 0.279 & 0.043 \\
\hline & CD $(5 \%)$ & 4.977 & & 0.871 & 0.134 \\
\hline
\end{tabular}

* Average of four replications

Table.4 Effect of light duration on mycelial growth and biomass of $H$. ulmarius.

\begin{tabular}{|c|c|c|c|c|c|}
\hline S.N. & Treatments & $\begin{array}{l}\text { Radial } \\
\text { growth } \\
(\mathbf{m m}) *\end{array}$ & Growth characteristics & $\begin{array}{l}\text { Fresh mycelial } \\
\text { weight (g.)* }\end{array}$ & $\begin{array}{l}\text { Dry mycelial } \\
\text { weight } \\
(\text { g. })^{*}\end{array}$ \\
\hline 1 & $\begin{array}{l}\text { Complete } \\
\text { darkness }\end{array}$ & 89.00 & $\begin{array}{l}\text { Absolute white mycelia growth suppressed } \\
\text { growth in the centre and raised growth from } \\
\text { concentric region, smooth margin with and } \\
\text { concentric rings. }\end{array}$ & 8.62 & 0.69 \\
\hline 2 & $\begin{array}{l}\text { 6hr. light }+18 \\
\text { hr. darkness }\end{array}$ & 79.50 & $\begin{array}{c}\text { Absolute white mycelia growth, fluffy in } \\
\text { nature with concentric rings with regular } \\
\text { margin. }\end{array}$ & 6.65 & 0.51 \\
\hline 3 & $\begin{array}{l}12 \text { hr alternate } \\
\text { dark and light }\end{array}$ & 83.25 & $\begin{array}{l}\text { Absolute white with concentric rings raised } \\
\text { margin. }\end{array}$ & 8.13 & 0.51 \\
\hline 4 & $\begin{array}{l}18 \text { hr. light + } 6 \\
\text { hr. darkness }\end{array}$ & 69.25 & $\begin{array}{l}\text { Dirty white with three concentric rings, } \\
\text { raised growth on concentric rings and } \\
\text { peripheral slight raised growth. }\end{array}$ & 7.54 & 0.32 \\
\hline 5 & 24hr. light & 80.25 & $\begin{array}{l}\text { Absolute white fluffy mycelia growth with } \\
\text { concentric rings irregular margin. }\end{array}$ & 7.99 & 0.56 \\
\hline & SEm \pm & 0.649 & & 0.421 & 0.035 \\
\hline & CD (5\%) & 1.973 & & 1.279 & 0.107 \\
\hline
\end{tabular}

* Average of four replications. 
Table.5 Effect of different levels of $\mathrm{pH}$ on mycelial growth of $H$. ulmarius.

\begin{tabular}{|c|c|c|c|}
\hline S.N. & Levels of pH & $\begin{array}{l}\text { Radial growth } \\
\qquad(\mathrm{mm}) *\end{array}$ & Growth characteristics \\
\hline 1 & 4 & - & No growth \\
\hline 2 & 5 & 58.000 & $\begin{array}{l}\text { Absolute white fluffy growth with concentric } \\
\text { rings and margin irregular. }\end{array}$ \\
\hline 3 & 6 & 69.000 & $\begin{array}{c}\text { Absolute white mycelial growth with concentric } \\
\text { rings and margin irregular. }\end{array}$ \\
\hline 4 & 7 & 75.750 & $\begin{array}{l}\text { White mycelial growth with concentric rings } \\
\text { and margin irregular. }\end{array}$ \\
\hline \multirow[t]{3}{*}{5} & 8 & 88.750 & $\begin{array}{l}\text { White mycelial growth with concentric rings } \\
\text { and margin regular. }\end{array}$ \\
\hline & CD $(5 \%)$ & 5.711 & \\
\hline & SEm \pm & 1.877 & \\
\hline
\end{tabular}

* Average of four replications

Fig.1 Effect of different media on mycelial growth of $H$. ulmarius
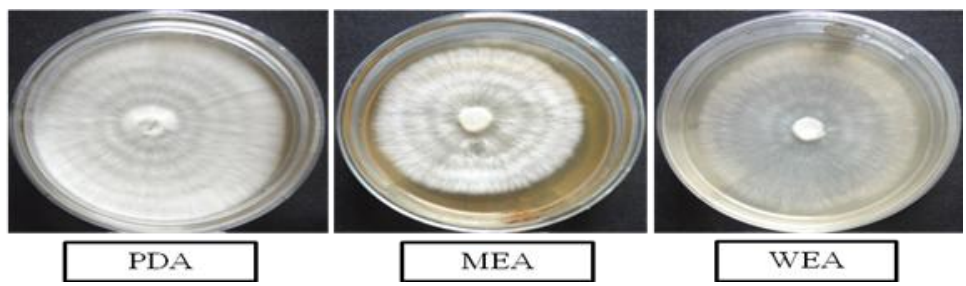

Fig.2 Effect of different temperature on mycelial growth of $H$. ulmarius

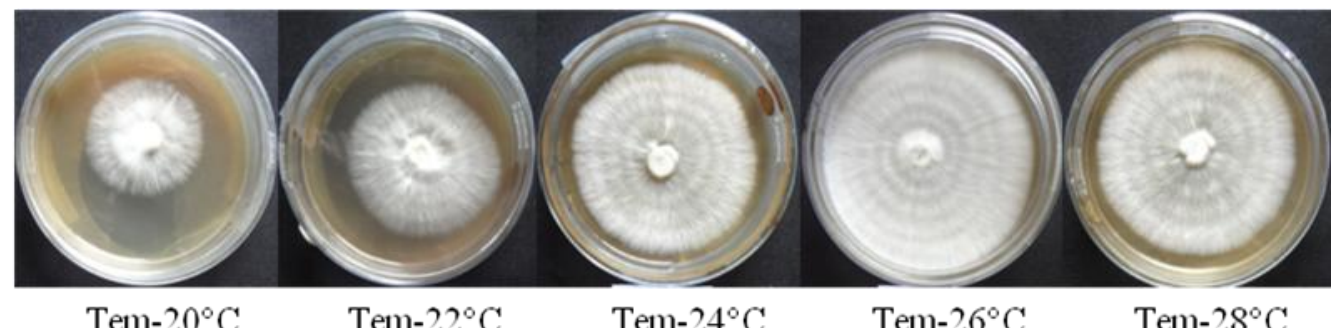


Fig.3 Effect of different levels of relative humidity on mycelial growth of H. ulmarius

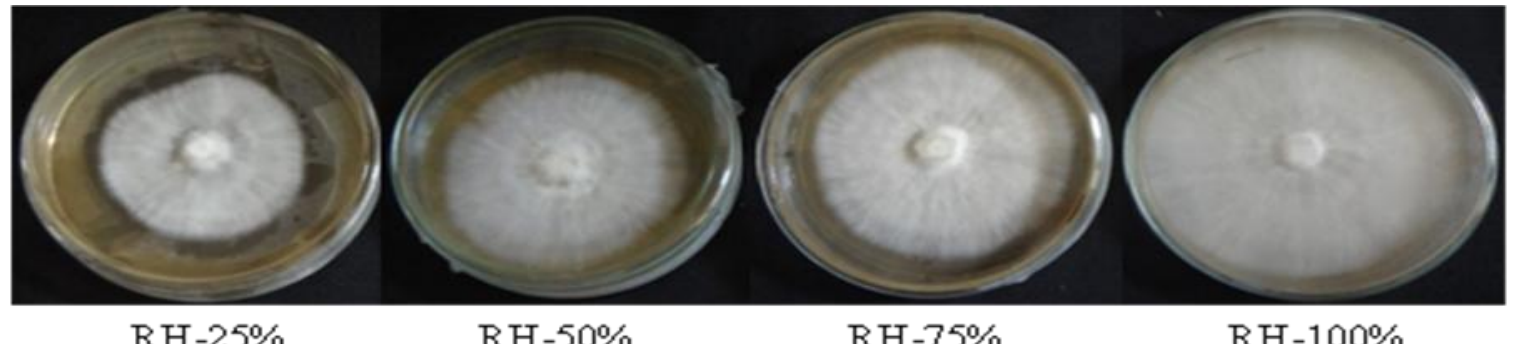

Fig.4 Effect of light duration on mycelial growth of $H$. ulmarius

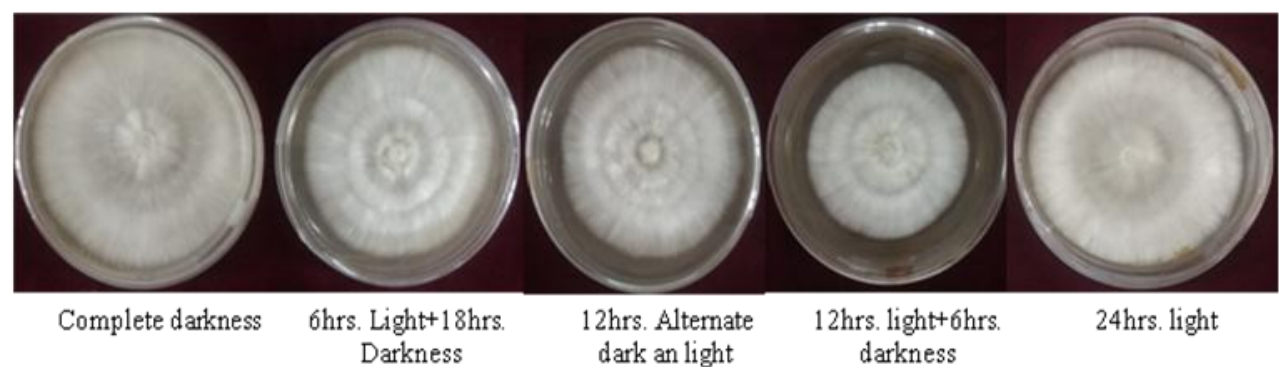

Fig.5 Effect of different levels of $\mathrm{pH}$ on mycelial growth of $H$. ulmarius.

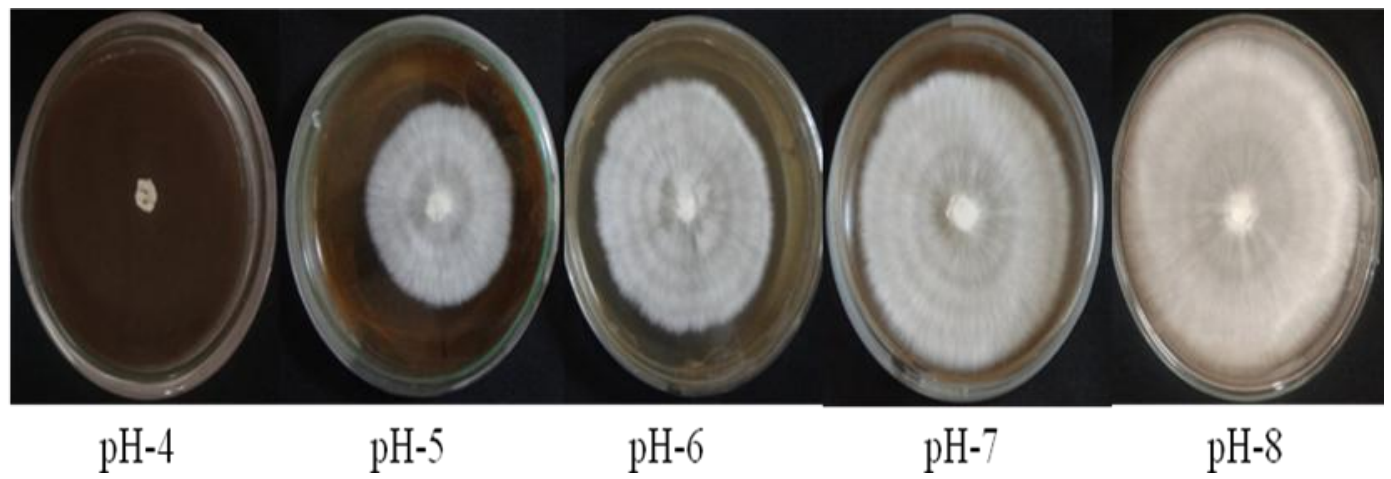

The present results are corroborating with the findings of Sharma (2004) who reported significantly higher radial growth of $P$. djamor under complete darkness.

\section{Effect of pH on radial growth of Hypsizygus ulmarius}

Different levels of $\mathrm{pH}$ showed significant difference in radial growth of $H$. ulmarius. Among the evaluated $\mathrm{pH}, \mathrm{pH} 8.0$ gave significantly more $(88.75 \mathrm{~mm})$ radial growth of $H$. ulmarius and next was $7.0 \mathrm{pH}$ (75.75 $\mathrm{mm})$ while it was significantly least noted at $\mathrm{pH} 5.0(59.00 \mathrm{~mm})$ and $6.0 \mathrm{pH}(69.00)$ but they were significantly differ with each other. No growth was observed at $\mathrm{pH} 4.0$ (Fig. 5).

The mycelial growth was white growth with concentric ring and margin regular at $\mathrm{pH} 8.0$, but in case of $\mathrm{pH} 5.0$ and 6.0 mycelial growth was absolute white with concentric rings and 
irregular margin, whereas at $\mathrm{pH} 7.0$ mycelial growth was white with concentric ring with irregular margin (Table 5). The present findings are partially in agreement with the work carried out by Sumi and Geetha (2016), Kumar et al., (2016) and Kushwaha et al., (2011).

Potato dextrose agar medium was found most suitable medium for the growth and biomass of $\mathrm{H}$. ulmarius. The temperature $26^{\circ} \mathrm{C}$ found as most appropriate for maximum radial growth and biomass of $H$. ulmarius.

Maximum radial growth and biomass was observed at $75 \%$ relative humidity. Complete darkness and $12 \mathrm{hrs}$ light duration were excellent for mycelial growth and biomass of H. ulmarius. Maximum mycelial growth of $H$. ulmarius was obtained at $\mathrm{pH} 8.0$ in PDA medium.

\section{References}

Anonymous. 2005. Annual report 2004-2005. All India Coordinated Mushroom Improvement Project, Centre Raipur (C.G.).

Chanravanshi, P. 2007. Studies on blue oyster mushroom (Hypsizygus ulmarius,
Bull.ex.Fr.). M.Sc. Thesis submitted to Deptt. of Plant Pathology, IGKV, Raipur, p.27.

Hilmer, O.1977. Methodik einer reschem fruchtkorper-bildungdes austernsei things zur verfolgungder merk malsk onstanz. schweiz. Z. pilzkd., 55 (6): 8788.

Kushwaha, K.P.S., Singh, P.K., Mishra, K.K. and Bhardwaj, S.B. 2011. Cultural and morphological studies of Hypsizygus ulmarius, blue oyster mushroom. Pantnagar Journal of Research, 9(2): 202-205

Namdev, J.K. 2000. Studies on production and preservation techniques of oyster mushroom (Pleurotus flabellatus), M.Sc.(Ag.) Thesis I.G.K.V, Raipur, (C.G.).

Sharma, B.B.2004. Effect of duration of light on radial growth of pink oyster Mushroom. Indian Phyto Pathology, 57 (2): 234.

Sumi, I. and Geetha, D. 2016. Physiological and cultural studies on blue oyster mushroom, Hypsizygus ulmarius (Bull.: Fr.) redhead. International Journal of Applied and Pure Science and Agriculture, 2(6): 2394-5532.

\section{How to cite this article:}

Dheeraj Baghel, Veer Singh, C. S. Shukla and Singh, H. K. 2019. Studies on Nutritional and Physiological Requirement for Growth and Biomass of Hypsizygus ulmarius. Int.J.Curr.Microbiol.App.Sci. 8(12): 169-176. doi: https://doi.org/10.20546/ijcmas.2019.812.025 